RESEARCH ARTICLE

\title{
Conservation attempt of critically endangered mangrove Lumnitzera littorea (Jack) Voigt in Madu Ganga Ramsar Site of Sri Lanka; stand composition and seed germination
}

\author{
P.L.M.M. Perera ${ }^{1, *}$, K.M.G.G. Jayasuriya ${ }^{1,2}$, A.M.T.A. Gunaratne ${ }^{1,2}$, W.A.I.P. Karunaratne ${ }^{1,3}$, \\ J.W. Damunupola ${ }^{1,2}$ and M.G.M. Prassanna ${ }^{4}$ \\ ${ }^{1}$ Postgraduate Institute of Science, University of Peradeniya, Peradeniya, Sri Lanka \\ ${ }^{2}$ Department of Botany, Faculty of Science, University of Peradeniya, Peradeniya, Sri Lanka \\ ${ }^{3}$ Department of Zoology, Faculty of Science, University of Peradeniya, Peradeniya, Sri Lanka \\ ${ }^{4}$ Ministry of Mahaweli Development and Environment, 416/C/1, Robert Gunawardana MW, Baththaramulla, Sri Lanka
}

Received: 26/02/2019 ; Accepted: 10/06/2019

\begin{abstract}
Considering the environmental and specific socioeconomic significance of the critically endangered mangrove Lumnitzera littorea, this study was conducted aiming the conservation of the species. The specific objectives were to define the diversity of the other mangrove species in association with the existing L. littorea plant population in the Madu Ganga wetland, Sri Lanka, to study its seed germination and identify the barriers for seed germination. The existing population of L. littorea is an aged population with low regeneration potential. Most of the seeds collected at the dispersal maturity were empty. A micro moth belonging to Family Gelechiidae was identified as the embryo predator. Although GA3 (Gibberellic acid) treatment and dry storage reduced the germination time, none of the seed treatments significantly improved the seed germination of $L$. littorea. Low seed germination observed was due to absence of embryo in mature seeds as a result of insect predation and physiological dormancy of seeds. Optimum GA3 concentration, duration of dry storage and potting medium with suitable salt concentration for seedlings should be optimized in future research.
\end{abstract}

Keywords: Lumnitzera littorea, seed germination, diversity, seed dormancy.

\section{INTRODUCTION}

Lumnitzera littorea (Jack) Voigt (E: Red Teruntum, S: Rathamilla) of Family Combretaceae is a true mangrove indigenous to Sri Lanka (Dassanayake et al., 1995). Although this species has a wide distribution in tropical Asia, Northern Australia and Polynesia, locally it was only known from few locations. In 1894, Trimen has recorded a population of Lumnitzera coccinea (Wight \& Arn.), (a synonym of L. littorea) in Benthota estuary, Sri Lanka (de Silva and de Silva, 2006). However, this population was not observed recently and considered as destroyed (Prassanna and Ranawana, 2014). A second population of L. littorea plants was discovered in 1983 in the Balapitiya estuary and thus, Jayatissa et al. (2002) has reported L. littorea as a rare species with a restricted distribution to Balapitiya estuary. At present mangrove scrub vegetation located in the Pathamulla area of the lower reaches of Madu Ganga wetland is the only habitat of this species remaining in Sri Lanka (Bambaradeniya et al., 2002; Jayatissa et al., 2002; Prasanna and Ranawana, 2014). Further, this remaining plant population is restricted to few trees and the mangrove ecosystem of the location is under immense pressure due to clearing for developmental purposes (personal observations). Thus, it is important to take immediate actions to conserve this critically endangered species to stop being extinct in the wild in Sri Lanka.

Lumnitzera littorea not only possess ecological significance but also it has many socio economic uses. In Thailand and Singapore, it is grown as an ornamental plant due to its conspicuous red flowers (Anonymous, 2017; Ellison et al., 2010). Heavy and fine-grained, durable yellow-brown wood is used for boat building and construction purposes and also as fuel. The species is planted along dykes of ponds (Anonymous, 2017; Ellison et al., 2010). L. littorea is traditionally known as a remedy for sprue. Bacteriostatic and bactericidal activities of $L$. littorea extracts against Staphylococcus aureus, Bacillus cereus and Escherichia coli suggest that the plant may possess therapeutic action in the treatment of infectious diseases caused by these microbes (Saad et al., 2011).

Lumnitzera littorea is an evergreen tree growing up to $8-15 \mathrm{~m}$ with terminally racemose conspicuous red inflorescences and woody fruits (Dassanayake et al., 1995) (Figure 1). Further, it is an out-crossing non viviparous species (Raju et al., 2014). As reported by Tomlinson (1994), although the fruit set is high in $L$. littorea, a high percentage of mature fruits have aborted embryos. Regeneration length of the species is 40 years. However, no literature was found with special reference to seed germination of L. littorea. There are only two species in the genus Lumnitzera (Mabberley, 2013), where the other species, L. racemosa Willd. (S: Beriya) is also a true mangrove with extended distribution in East Africa and Madagascar (Dassanayake et al., 1995; Senaratna, 2001). Lumnitzera racemosa is pollinated predominantly by day-active insects (Tomlinson, 1994) such as bees, wasps, diurnal moths and butterflies (Raju et al., 2014). 
Vivipary or cryptovivipary is not observed in Lumnitzera spp. and buoyant fruits get dispersed by water currents (FAO, n.d.). Natural regeneration of L. racemosa is low as high percentage of mature fruits is commonly empty due to abortion of embryos. Sometimes embryos are also eaten by grubs that emerge from the eggs laid by parent insects in the early stages of fruit development (Tomlinson, 1994).

Yong et al., (2004) reported that fruits of L. racemosa planted immediately after collection, failed to germinate in Hong Kong. However, fruits kept under wet storage; i.e. wet with tap water and stored in sealed plastic bags and kept in shade under room temperature for 35 or 50 days germinated successfully. However, the fruits kept under dry storage in a cabinet under room temperature of about $25{ }^{\circ} \mathrm{C}$ became black with dead embryos after one month of storage. Fruits subjected to wet storage for 35 days germinated, with roots initiated after 12 days of planting. Even after breaking dormancy, the percentage germination was still as low as $20 \%$ after 23 days. Hettiarachchi et al. (2002) have reported that attempts to propagate $L$. littorea by seeds had failed, although the vegetative propagation by air layering and girdle cuttings was successful in Sri Lanka. However, limited information is available in this publication on the propagation of this species.

Considering the environmental and socio-economic significance, restricted distribution to Madu Ganga wetland of Sri Lanka and the critically endangered status, the current study was aimed to define the diversity of the other mangrove species in association with the existing plant population of its only remaining site and to study seed germination biology of $L$. littorea.

\section{MATERIALS AND METHODS}

\section{Study site and collection of fruits}

The current study location was the only existing location of L. littorea in Sri Lanka, a private land in Pathamulla, Balapitiya located in the Madu Ganga RAMSAR site and the sanctuary $\left(06.26896^{\circ} \mathrm{N}, 080.04286^{\circ} \mathrm{E}\right.$ and $06.26867^{\circ}$ $\mathrm{N}, 080.04247^{\circ} \mathrm{E}$ ) (Figure 2).
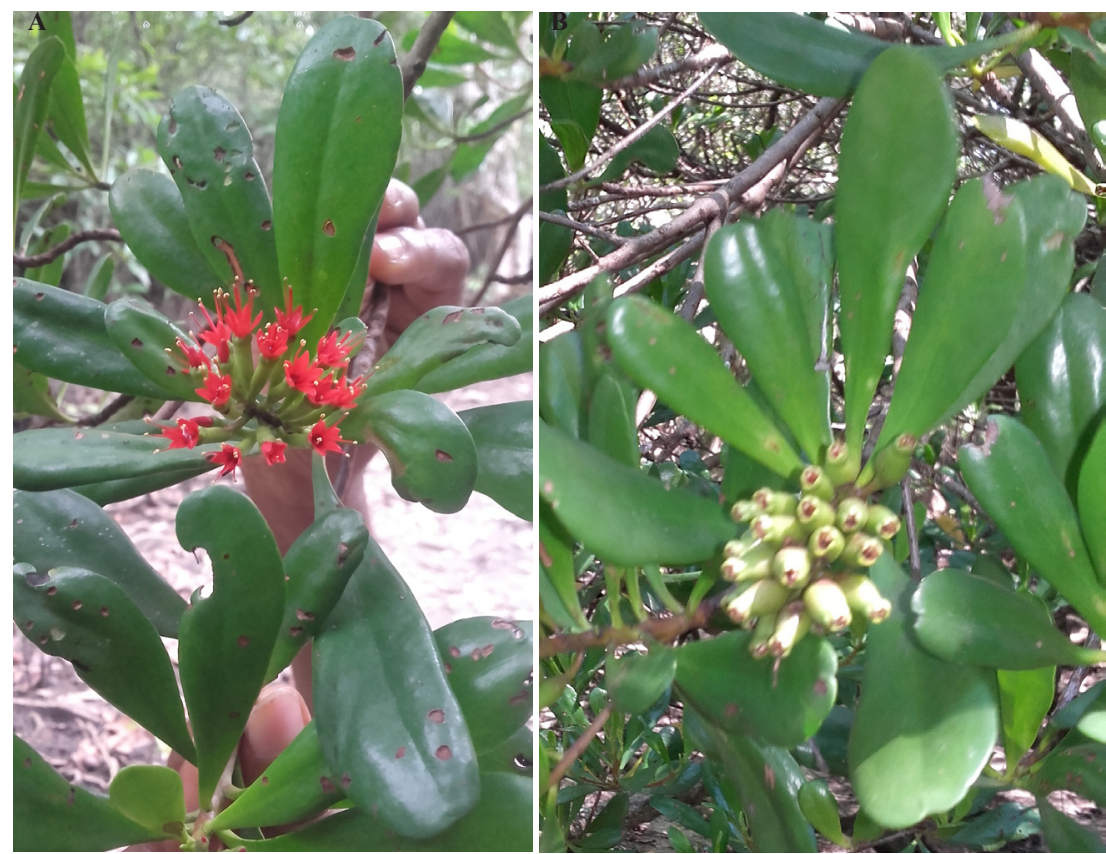

Figure 1: Some important characters of L. littorea plant; A) red conspicuous flowers and B) fruits.

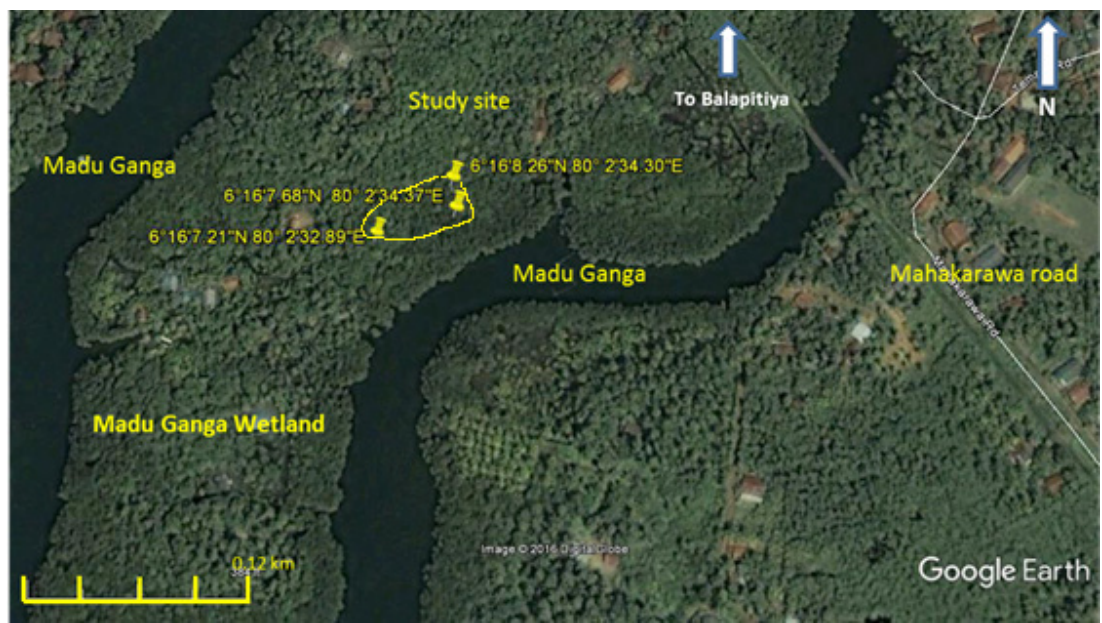

Figure 2: Study site in the Madu Ganga wetland. Pins indicate the locations of some L. littorea trees in the boundary of the existing population, which is demarcated by the line connecting the pins (modified map from Google Earth from www.google.lk; downloaded on 14/04/2017). 
Site visits for sample collection and observations were conducted from February 2017 to January, 2018. Ripened fruits evident by yellow and light green colour with a shiny pericarp were collected from mature trees. Fruits collected from the ground had a brown to black fibrous pericarp most of the time. Two fruiting seasons were recorded in the field visits; November-December and April-May. Fruits were collected to polythene bags and brought to the University of Peradeniya, Sri Lanka where all the laboratory experiments were conducted. Fruits were used as the propagation unit as each fruit includes one seed covered by fibrous pericarp.

\section{Determining the plant diversity associated with existing L. littorea population of the site}

The $L$. littorea existing site was divided into three $10 \mathrm{~m} \times 10$ $\mathrm{m}$ plots covering the whole area of $L$. littorea existed. Species and the number of individuals of trees, saplings and seedlings within each plot were recorded. For this study, a tree was defined as a plant taller than $2 \mathrm{~m}$, while a seedling as shorter than $30 \mathrm{~cm}$ and a sapling as a plant between $30 \mathrm{~cm}$ and $2 \mathrm{~m}$ in height. Diameter at breast height (dbh) of each tree was measured in inches using a diameter tape (Art.-Nr.5896 N). When a tree had two trunks, dbh of the larger trunk was recorded as the dbh of the plant. When a tree was in an angle to the ground, $1.3 \mathrm{~m}$ breast height was measured along the trunk from the ground (Kathiresan and Khan, 2010).

\section{Assessment of fruit moisture content}

Four samples of ten tree-collected fruits each were weighed separately with a digital chemical balance. Samples were oven dried at $120^{\circ} \mathrm{C}$ for 3 hours, retrieved and reweighed. Fruit moisture content was calculated to the fresh mass basis using the following formula,

$$
\begin{aligned}
& \text { Fruit Moisture Content (Fresh Mass Basis) }= \\
& \qquad \frac{\text { nitial Weight }- \text { Oven Dry Weight }}{\text { Initial Weight }} \times 100 \%
\end{aligned}
$$

\section{Standard germination of fruits}

Four replicates of fifteen ground-collected and tree-collected fruits were incubated separately on tissue papers moistened with distilled water in 9-cm-diameter Petri dishes. These were incubated at ambient laboratory temperature and light conditions. Fruits were observed for germination in 3-day intervals for 30 days. Radicle emergence was the criterion for germination.

\section{Effect of different treatments on fruit germination}

Tree-collected fruits of L. littorea (sample B) and groundcollected fruits of $L$. littorea (sample C) with the highest possible number of replicates depending on the availability of fruits (minimum three replicates), were subjected to different treatments as mentioned in Table 1. Fruits were incubated on tissue papers moistened with distilled water or $\mathrm{GA}_{3}$ (Gibberellic acid) solution once a week according to the treatment. Fruits were observed for germination in 3-day intervals for at least 30 days. Radicle emergence was the criterion for germination.

\section{Seedling propagation}

Seedlings of all the germinated seeds were potted in two different potting media; top soil: compost in 1:1 ratio 1-30 seedlings and sand: compost in 1:1 ratio in $10 \mathrm{~cm}$ diameter plastic pots. Seedlings were kept under ambient plant house temperature $\left(\sim 27^{\circ} \mathrm{C}\right)$ and light conditions.

Seedlings were watered with tap water as required. Shoot length of the seedlings was measured to the nearest $\mathrm{mm}$ in 7-day intervals from the date of germination until they were dead.

\section{Investigating the impact of insect seed predation on germination of $L$. littorea fruits}

Four replicates of ten seeds each from ground-collected and tree-collected fruits were longitudinally cut and observed for the presence/ absence of the embryo and presence/ absence of the caterpillar.

Flowers at two different developmental stages; inflorescences with opened florets and inflorescences with unopened flower buds in L. littorea plants were selected and covered with mosquito nets with $0.5 \mathrm{~mm}$ mesh size (Table 2). Fruits developed from the covered inflorescences were collected after seven weeks and incubated on tissue papers moistened with distilled water at ambient room temperature and light conditions for 30 days. Fruits were observed for the emergence of insects. At the end of the incubation period incubated fruits were cut longitudinally along the center and observed for the presence of embryo.

\section{Identification of the moth emerged from fruits}

Insect specimens were observed under the light microscope. Specimens were photographed with Optica Vision Lite 2.1 software. The insect was identified up to the family level using Britton et al., (1970).

\section{Data analysis}

All the lab experiments were conducted in a completely randomized design. MINITAB 14 software was used in data analysis. Mood's median test was performed at 0.05 level of significance to determine whether any seed germination treatment used has significantly improved the germination of seeds.

\section{RESULTS}

\section{Plant diversity associated with the existing $L$. littorea population}

Four plant species; Excoecaria agallocha (Euphorbiaceae), Heritiera littoralis (Sterculiaceae), Dolichandrone spathacea (Bignoniaceae) and Cerbera odollam (Apocynaceae) were recorded in association with $L$. littorea in the study site. Among them E. agallocha and $H$. littoralis are true mangroves, while the other two species are mangrove associates.

A total of 18 trees of L. littorea were present in the 
Table 1: Treatments performed for fruit samples in the germination experiments.

\begin{tabular}{|c|c|c|c|c|c|}
\hline Treatment & Sample & $\begin{array}{l}\text { No: of fruits in each } \\
\text { replicate } \times \text { No: of } \\
\text { replicates }\end{array}$ & Treatment & Sample & $\begin{array}{l}\text { No: of fruits in } \\
\text { each replicate } \times \\
\text { No: of replicates }\end{array}$ \\
\hline \multirow[t]{2}{*}{$\mathrm{d} / \mathrm{w}$} & $\mathrm{B}$ & $15 \times 8,10 \times 6$ & 100 ppm GA, 4wds & $\mathrm{B}$ & $10 \times 6$ \\
\hline & $\mathrm{C}$ & $15 \times 8,10 \times 7$ & & $\mathrm{C}$ & $10 \times 4$ \\
\hline \multirow[t]{2}{*}{100 ppm GA } & B & $15 \times 2,10 \times 6$ & 100 ppm GA, 5wds & $\mathrm{B}$ & $10 \times 5$ \\
\hline & $\mathrm{C}$ & $15 \times 2,10 \times 7$ & & $\mathrm{C}$ & $10 \times 5$ \\
\hline \multirow[t]{2}{*}{500 ppm GA } & $\mathrm{B}$ & $15 \times 2,10 \times 6$ & 100 ppm GA, 6wds & $\mathrm{B}$ & $10 \times 3$ \\
\hline & $\mathrm{C}$ & $15 \times 2,10 \times 7$ & & $\mathrm{C}$ & $10 \times 3$ \\
\hline \multirow[t]{2}{*}{$\mathrm{d} / \mathrm{w}, 1 \mathrm{wds}$} & $\mathrm{B}$ & $10 \times 3$ & 100 ppm GA, 7wds & $\mathrm{B}$ & $10 \times 3$ \\
\hline & $\mathrm{C}$ & $10 \times 3$ & & $\mathrm{C}$ & $9 \times 3$ \\
\hline \multirow[t]{2}{*}{$\mathrm{d} / \mathrm{w}, 2 \mathrm{wds}$} & B & $10 \times 3$ & 100 ppm GA, 8wds & B & $10 \times 2$ \\
\hline & $\mathrm{C}$ & $10 \times 3$ & & $\mathrm{C}$ & $10 \times 1$ \\
\hline \multirow[t]{2}{*}{$\mathrm{d} / \mathrm{w}, 3 \mathrm{wds}$} & $\mathrm{B}$ & $10 \times 3$ & $100 \mathrm{ppm}$ GA, $12 \mathrm{wds}$ & $\mathrm{B}$ & $10 \times 1$ \\
\hline & $\mathrm{C}$ & $10 \times 3$ & & & \\
\hline \multirow[t]{2}{*}{$\mathrm{d} / \mathrm{w}, 4 \mathrm{wds}$} & $\mathrm{B}$ & $10 \times 6$ & 500 ppm GA, 1wds & $\mathrm{B}$ & $10 \times 3$ \\
\hline & $\mathrm{C}$ & $10 \times 4$ & & $\mathrm{C}$ & $10 \times 3$ \\
\hline \multirow[t]{2}{*}{$\mathrm{d} / \mathrm{w}, 5 \mathrm{wds}$} & $\mathrm{B}$ & $10 \times 5$ & 500 ppm GA, 2wds & $\mathrm{B}$ & $10 \times 3$ \\
\hline & $\mathrm{C}$ & $10 \times 5$ & & $\mathrm{C}$ & $10 \times 3$ \\
\hline \multirow[t]{2}{*}{$\mathrm{d} / \mathrm{w}, 6 \mathrm{wds}$} & $\mathrm{B}$ & $10 \times 3$ & 500 ppm GA, 3wds & $\mathrm{B}$ & $10 \times 3$ \\
\hline & $\mathrm{C}$ & $10 \times 3$ & & $\mathrm{C}$ & $10 \times 3$ \\
\hline \multirow[t]{2}{*}{$\mathrm{d} / \mathrm{w}, 7 \mathrm{wds}$} & $\mathrm{B}$ & $10 \times 3$ & 500 ppm GA, 4wds & $\mathrm{B}$ & $10 \times 6$ \\
\hline & $\mathrm{C}$ & $9 \times 2$ & & $\mathrm{C}$ & $10 \times 4$ \\
\hline \multirow[t]{2}{*}{$\mathrm{d} / \mathrm{w}, 8 \mathrm{wds}$} & $\mathrm{B}$ & $10 \times 2$ & 500 ppm GA, 5wds & B & $10 \times 5$ \\
\hline & $\mathrm{C}$ & $9 \times 1$ & & $\mathrm{C}$ & $10 \times 5$ \\
\hline $\mathrm{d} / \mathrm{w}, 12 \mathrm{wds}$ & $\mathrm{B}$ & $10 \times 1$ & 500 ppm GA, 6wds & $\mathrm{B}$ & $10 \times 3$ \\
\hline \multirow[t]{2}{*}{100 ppm GA, 1wds } & B & $10 \times 3$ & & $\mathrm{C}$ & $10 \times 3$ \\
\hline & $\mathrm{C}$ & $10 \times 3$ & 500 ppm GA, 7wds & $\mathrm{B}$ & $10 \times 3$ \\
\hline \multirow[t]{2}{*}{100 ppm GA, 2wds } & $\mathrm{B}$ & $10 \times 3$ & & $\mathrm{C}$ & $9 \times 2$ \\
\hline & $\mathrm{C}$ & $10 \times 3$ & 500 ppm GA,8wds & B & $10 \times 2$ \\
\hline \multirow[t]{2}{*}{100 ppm GA, 3wds } & B & $10 \times 3$ & & $\mathrm{C}$ & $10 \times 1$ \\
\hline & $\mathrm{C}$ & $10 \times 3$ & 500 ppm GA, 12 wds & $\mathrm{B}$ & $10 \times 1$ \\
\hline
\end{tabular}

$\mathrm{d} / \mathrm{w}$; distilled water, B; tree-collected fruits of L. littorea, C; ground-collected fruits of L. littorea, wds; weeks dry storage

Table 2: Fruit samples of covered inflorescences incubated to observe insect emergence.

\begin{tabular}{cccc}
\hline \multirow{2}{*}{\begin{tabular}{c} 
Developmental stage at $\begin{array}{c}\text { the time of covering } \\
\text { Opened flowers }\end{array}$ \\
\cline { 2 - 4 }
\end{tabular}} & Replicates & $\begin{array}{c}\text { No: of replicates } \\
\text { incubated }\end{array}$ & $\begin{array}{c}\text { No: of fruits } \\
\text { in a replicate }\end{array}$ \\
\cline { 2 - 4 } & OF1 & 3 & 11 \\
\cline { 2 - 4 } & OF2 & 3 & 9 \\
\hline OF3 & 1 & 8 \\
\hline OF4 & 2 & 10 \\
\hline
\end{tabular}


study site (Figure 3 ). The number of seedlings of $L$. littorea observed in the site was low (2), whereas no saplings were recorded. As shown in Figure 4, three trees have been recorded in each dbh class between 50.1-90.0 cm. Out of the $18 \mathrm{~L}$. littorea trees more than two thirds (13) have dbh above $50.0 \mathrm{~cm}$. It was observed that in some L. littorea trees lower branches were completely defoliated, dried and decayed.

\section{Fruit moisture content}

Fresh mass of L. littorea was $0.065 \pm 0.016 \mathrm{~g}$ while the dry mass was $0.057 \pm 0.013 \mathrm{~g}$. Thus the moisture content of tree collected $L$. littorea seeds was $12.18 \pm 4.50 \%$ on fresh mass basis.

\section{Standard germination of fruits}

Only $3.3 \pm 5.2 \%$ of the non-treated L. littorea fruits plucked from trees germinated, while none of the nontreated ground-collected seeds germinated.

\section{Effect of different treatments on fruit germination}

Out of the 2612 fruits of $L$. littorea subjected to different treatments, only 14 fruits germinated during the study period. Ten of these were tree-plucked fruits, while only four were ground-collected fruits. None of the treatments significantly improved the germination of ground-collected or plucked $L$. littorea seeds (Figure 5). However, percentage germination of the fruits of L. littorea increased slightly when they were stored dry for five $(1.0 \%)$ and six weeks (1.1\%) compared to the non-stored fruits $(0.9 \%)$ (data not shown).

\section{Seedling propagation}

A sigmoidal curve was observed for shoot length increase of the seedlings of L. littorea with time (Figure 6). The maximum time period of survival of $L$. littorea seedlings was 33 days. Only 4 seedlings out of 14 survived $>20$ days in pots. The other 10 seedlings of $L$. littorea survived for an average of 15 days. The seedling of $L$. littorea survived for 33 days had a shoot length of $2.0 \mathrm{~cm}$ and the two seedlings

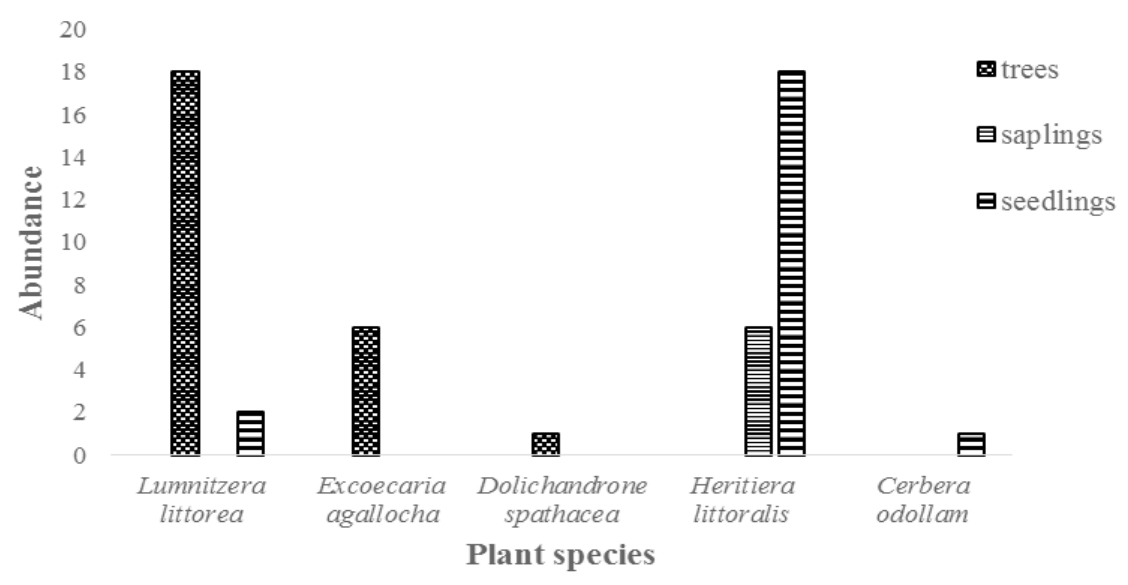

Figure 3: Total abundance of trees, saplings and seedlings of each plant species present in the study site $\left(300 \mathrm{~m}^{2}\right)$ where $L$. littorea known to occur in the Madu ganga RAMSAR site.

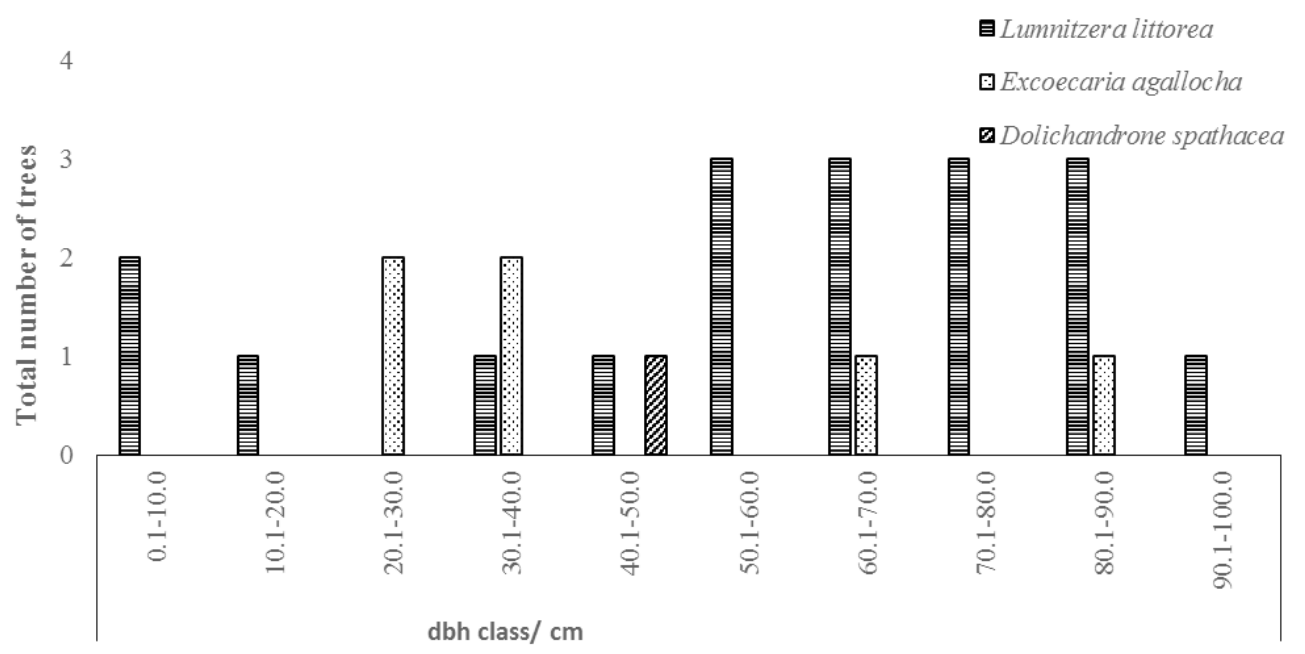

Figure 4: DBH classes of trees of each species in the study site $\left(300 \mathrm{~m}^{2}\right)$ where L. littorea known to occur in Madu ganga RAMSAR site. 


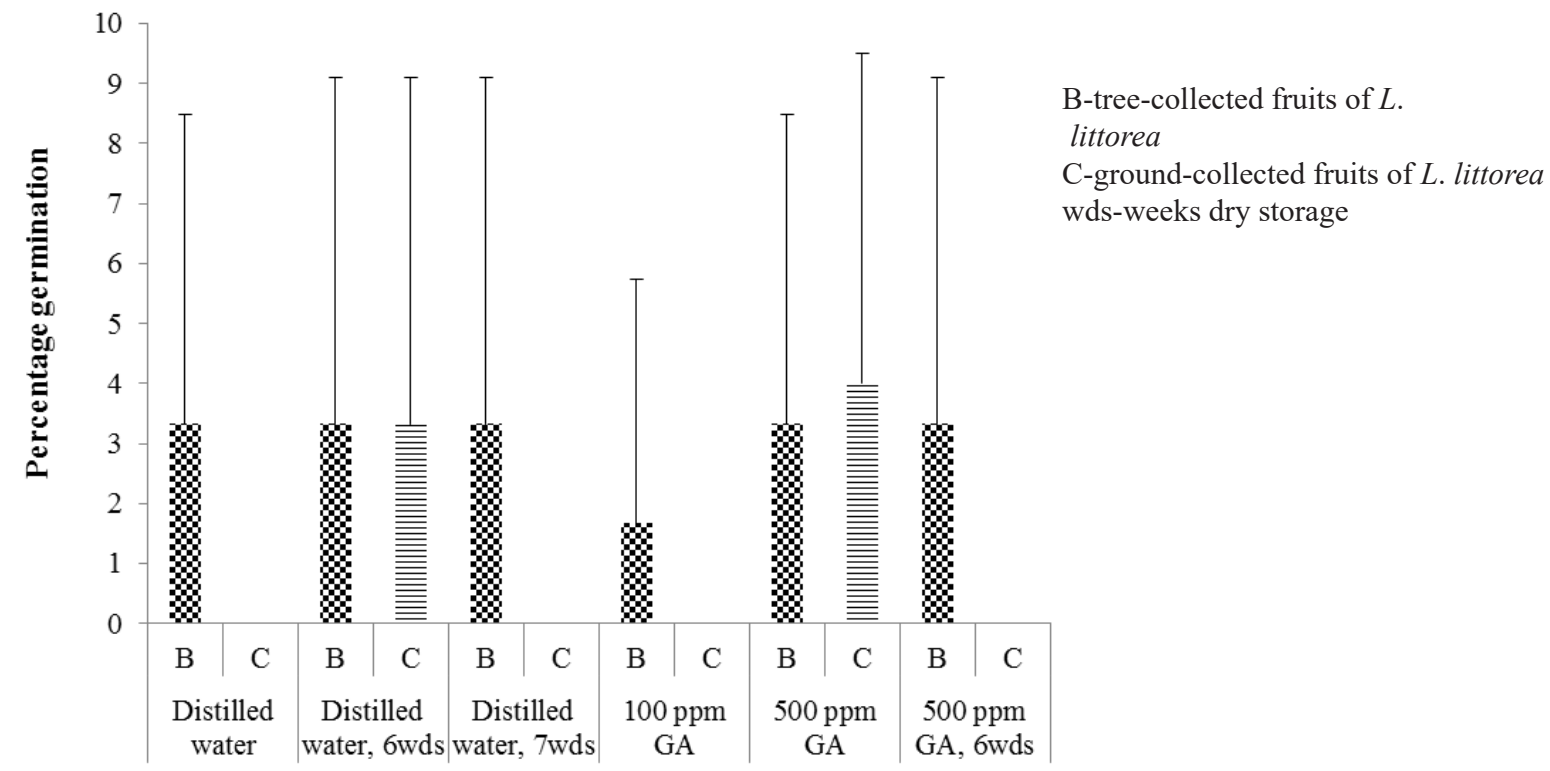

Treatment

Figure 5: Percentage germination of $L$. littorea seeds collected from the tree (B) or from the ground (C) at ambient laboratory temperature and light conditions on tissue papers moistened with distilled water or 100 or 500 ppm GA . Error bars are + SD. No significant differences were observed between treatments.

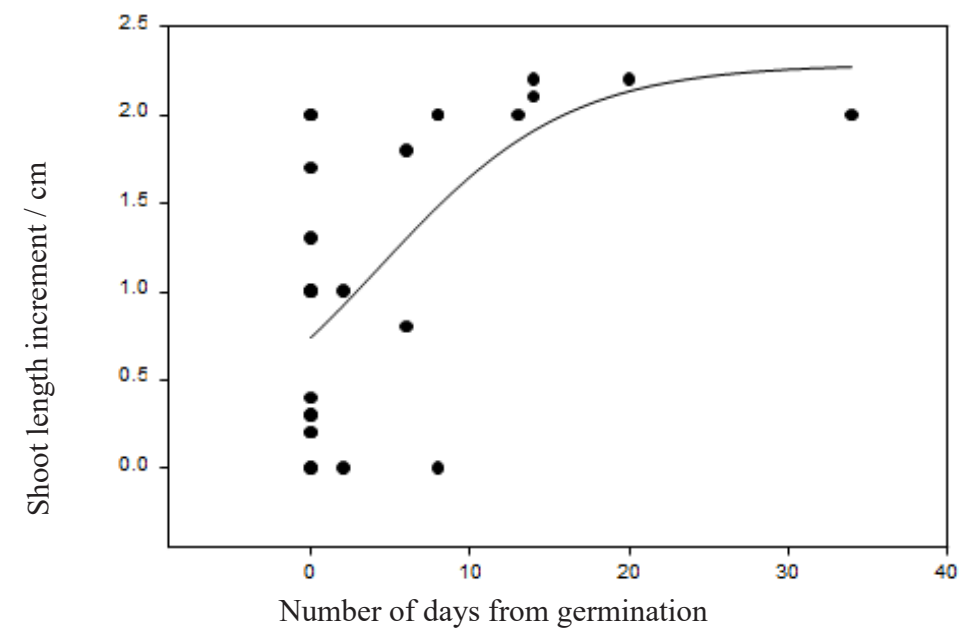

Figure 6: Shoot length increment of $L$. littorea seedlings grown in top soil:compost 1:1 or sand:compost $=1: 1$ media at ambient glass house temperature $\left(\sim 27^{\circ} \mathrm{C}\right)$ and light conditions. Weibul 4 parameter sigmoidal curve was fitted to describe the seedling development $\left(\mathrm{R}^{2}=0.36\right)$

that lived for 30 days were of 2.1 and $2.2 \mathrm{~cm}$ in length. Seedlings of $L$. littorea survived $<20$ days had an average shoot length of $0.6 \mathrm{~cm}$. All the seedlings remained without elongating after they reached their maximum shoot length for some time and then they all started to die. First, leaves of these seedlings were fallen, while the remaining green shoots became brown and shrunk in appearance. Roots were rotten.

\section{Impact of embryo predation on germination of $L$. littorea fruits}

Lower percentage $(23.31 \pm 5.82 \%)$ of ground-collected fresh fruits of L. littorea had embryos inside (Figure 7A and Figure 8). The rest either contained an insect larva or they were empty (Figure 7B). However, $40.00 \pm 10.01 \%$ of tree-plucked fresh fruits contained embryo, while the rest contained insect larvae or were empty. Percentage of fruits containing embryos was significantly different between ground-collected and tree-plucked fruit samples of $L$. littorea $(\mathrm{p}=0.014)$. Furthermore, insect larvae were present in tree-plucked fruits in a higher percentage than in ground-collected sample. Moths emerged only from treeplucked fruits and none from ground-collected fruits and this difference was significant $(p<0.001)$. 


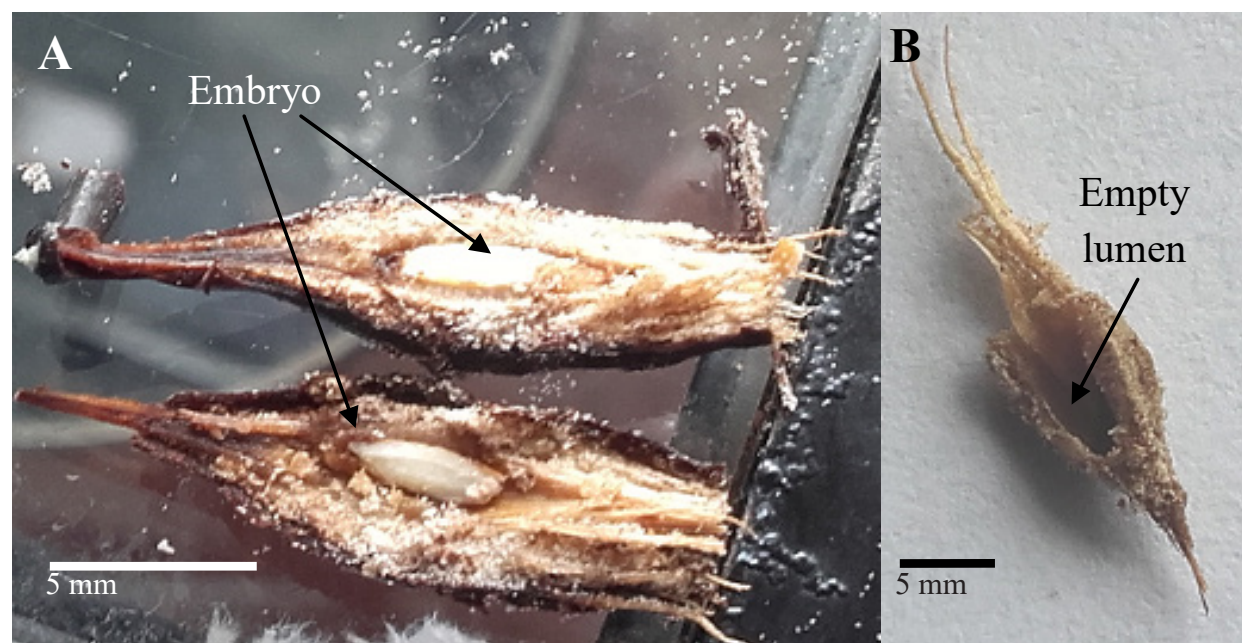

Figure 7: Longitudinally cut $L$. littorea fruits with and without embryo.

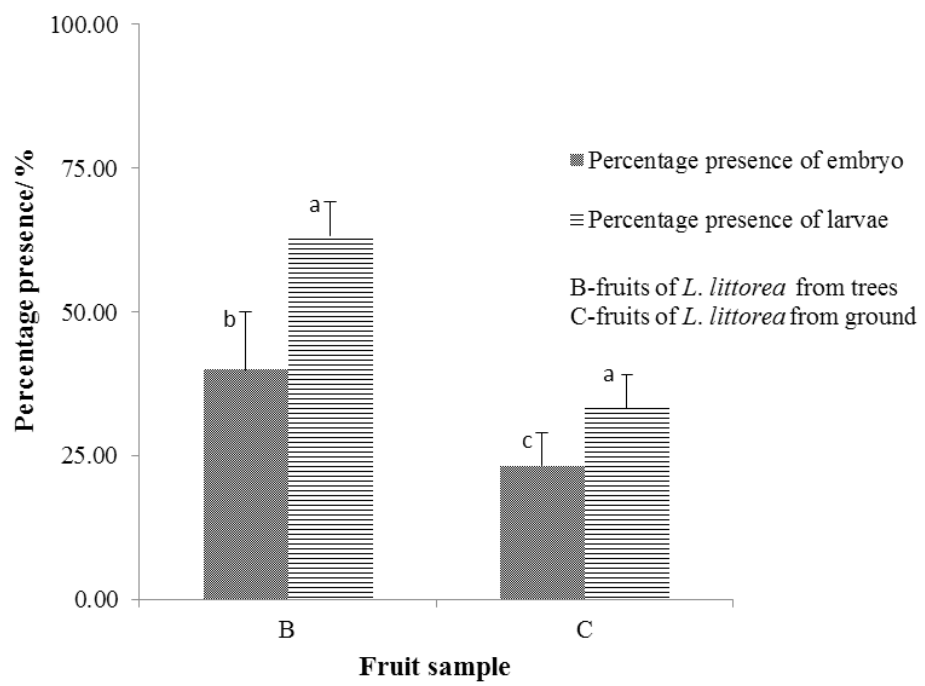

Figure 8: Percentage of fruits containing embryo and insect larvae in fresh fruits of L. littorea. Different letters indicate significant differences between treatments

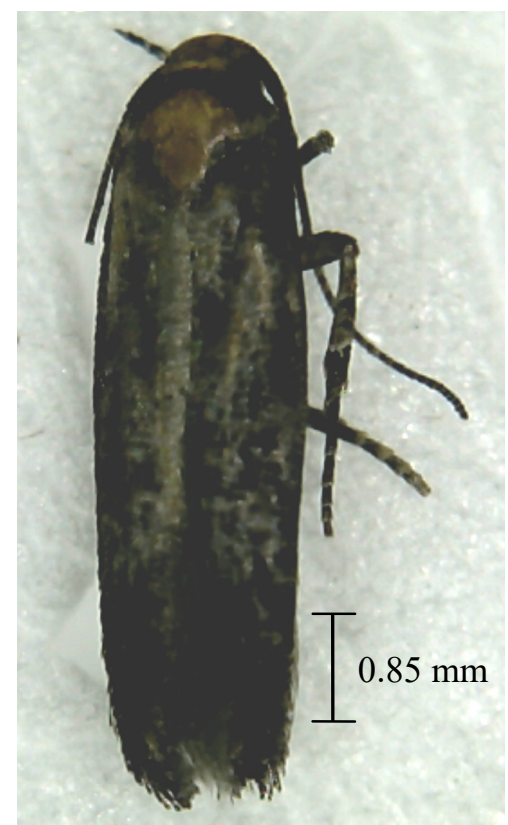

Figure 9: Light micrographs of the micro moth emerged from the fruits of L. littorea 
Fruits developed from the inflorescences covered at the stage of open flowers had $6.29 \pm 9.60 \%$ embryos while $9.09 \pm 0.00 \%$ fruits developed from inflorescences covered at closed bud stage had embryos. However, the difference was not statistically significant $(p=0.155)$. Seven moths emerged from 105 fruits developed from inflorescences covered at the open flower stage, whereas moths did not emerge from 22 fruits developed from inflorescences covered at the flower bud stage. However, there was no significant difference between the two treatments $(\mathrm{p}=$ $0.305)$.

\section{Identification of the moth emerged from fruits}

Light micrograph of the insect emerged from the incubated L. littorea fruits are shown in the figure 9. According to the morphology of the insect and the size $(<20 \mathrm{~mm})$, it was identified as a micro moth of the family Gelechiidae.

\section{DISCUSSION}

In Madu Ganga RAMSAR site; the only known current location of L. littorea in Sri Lanka, it coexists with several other true mangrove and mangrove associate species. Low abundance of seedlings and absence of saplings of $L$. littorea compared to other mangrove species in the site indicate the low regeneration potential of the species. Relatively high DBH of most of the trees further indicated that the existing population was an aged population. Low abundance of seedlings could be attributed to low seed germination, propagule predation by animals such as crabs, salinity and flooding stresses (Feller and Sitnik, n.d.) and low light penetration to the ground level due to continuous canopy. Low seed germination of Lumnitzera spp. has already been reported in other studies (Hettiarachchi et al., 2002; Yong et al., 2004) and also compatible with the results of this study.

The seedlings have tender and delicate tissues with high palatability and crabs in the site became more abundant with the long awaited rainfall. Thus, crabs could be a potential predator as mentioned in literature (Feller and Sitnik, n.d.) and suspected by the local people. Seedlings were observed closer to a footpath with high human disturbances and hence tend to be destroyed. Defoliation and dying of branches observed in some trees of the study site could be due to nutrient imbalances or soil toxicity that is more pronounced in water logging conditions or pathogens or herbivory on the plants (Kathiresan and Bingham, 2001).

Seed moisture content of $L$. littorea seeds is within the seed moisture content of orthodox seeds (Hong and Ellis, 1994). Thus, we can conclude that seeds of L. littorea are orthodox, i.e., desiccation tolerant. Percentage germination of both tree-plucked and ground-collected fruits of $L$. littorea showed overall low percentage germination with or without any seed treatments. Low germination could be due to aborted embryos in majority of mature fruits as reported by Tomlinson (1994) in Lumnitzera species. More than $75 \%$ of the ground-collected and tree-plucked fruits of L. littorea did not have embryos. Thus, predation of the embryo by an insect could be another reason for lower germination. Lower percentage germination of groundcollected fruits of L. littorea than that of the tree-plucked samples can be attributed to loss of viability of fruits during dispersal (Tomlinson, 1994). When getting dispersed by water currents, orthodox seeds of L. littorea reduce the viability. However, some fruits did not germinate in the seed germination experiment although embryos were present. These seeds may be either dormant or non-viable. However, Tetrazoilum experiment could not be performed to check the seed viability as presence of live insect larvae can also give false positive results indicating embryo viability.

Although none of the performed treatments significantly improved the germination of the seeds of L. littorea, GA3 and dry storage treatments reduced the germination time. Dry storage and $\mathrm{GA}_{3}$ treatments can reduce the germination time if seeds have physiological dormancy (see Baskin and Baskin, 2004 for more details about levels of physiological dormancy). Further, seeds of L. littorea did not germinate after seven weeks dry storage and this could be due to loss of viability. Only six weeks of dry storage was little successful in breaking the dormancy. This could be an indication of deep physiological dormancy. However, ground-collected seeds treated with 500 ppm GA3 after six weeks dry storage did not germinate. Ground-collected fruits of $L$. littorea neither germinated without treatment nor after $100 \mathrm{ppm}$ GA3 treatment. However, level of physiological dormancy could not be identified as only few seeds germinated under any seed treatment.

Confirming the predation of embryo of the fruits, micro moths emerged from the fruits incubated at ambient laboratory conditions. The insect observed in this study showed some similarities in foraging behavior to the leaf mining Thiotricha moth of Gelechiidae recorded previously from L. racemosa (Murphy, 1990). Sub-circular holes of mature leaves of L. racemosa are produced by a leaf mining Thiotricha spp. of Family Gelechiidae. They first attack the fruit by penetrating and hollowing which is then used as a portable case. The growing larvae damage several fruits before moving to the foliage and causes loss of developing fruits. In foliage it attachés the case with silk and excavates a mine to a radius it can reach. Heavily infested plants have shriveled fruits attached to the foliage. Tiny white moths fly around the host in day time. However, slightly larger fruits of $L$. littorea have not been recorded to suffer from this attack but larvae transferred from L. racemosa accepted $L$. littorea foliage and completed the development. Similarly, in this study, circular and irregular shaped holes were observed in the mature leaves of L. littorea. Empty fruits without embryos were also encountered in the study. Most Thiotricha species have been reported as foliage or leaf litter feeders. However, Fujita et al. (2009) has shown that $T$. pancratiastis larvae extensively feed on bayberry seeds making them non-viable. However, more studies are needed to identify the micro-moths observed to the species level.

Since some moths have emerged from the fruits of open flowers and no moths from the fruits developed from closed flower buds, it is possible that the adult insect visits open inflorescences. However, this has to be reinforced with more replicates. As moths emerged only from tree-plucked fruits and none from ground-collected 
samples, it is possible that the adult moth attacks the fruits attached to the plant. It could lay eggs by penetrating and hollowing the fruit. Larvae may be feeding on the embryo while growing into an adult and leaving before the mature fruit falls. Single larvae growing inside the fruit damages several fruits before becoming an adult and causes the loss of developing fruits (Murphy, 1990).

Since dry storage and GA3 treatment were identified as dormancy breaking treatments, optimum GA3 concentration and optimum period of dry storage should be determined in further studies. Duration of survival of seedlings should be increased with optimum salt and nutrient concentrations of the potting medium and controlled temperature and humidity. Seedlings should be maintained under shady conditions in a plant nursery. Before planting in the field, seedlings should be gradually acclimatized to the field conditions such as high light intensity and salt concentrations. Soil nutrient content within L. littorea population should be analyzed in future research to identify any nutrient imbalances accounting for the defoliation and death of branches. Seedling predators could be identified by setting camera traps in the site. Recorded micro moth species should be identified to confirm its impact on seed germination of $L$. littorea. The stage of flower development in which the moth attacks should be confirmed with more replicates of inflorescences covered at different stages of development.

\section{CONCLUSION}

The only remaining population of L. littorea in the Madu Ganga RAMSAR site Sri Lanka is an aged population with low regeneration potential and low seed germination. None of the treatments significantly improved the germination of seeds. Physiological dormancy of seeds, absence of embryo and embryo damage by the recorded micro moth belonging to Family Gelechiidae were identified as reasons for low germination of L. littorea in this study.

\section{REFERENCES}

Anonymous. (2017). Useful tropical plants; Lumnitzera littorea. Available from tropical.theferns.info/ viewtropical.php (Accessed 10 February, 2017).

A.O.A.C. (1984). Official Methods of Analysis of the Association of Official Analytical Chemist s' $14^{\text {th }}$ Ed. Published by the Association of Official Analytical Chemist s', Arlington, Virginia, 22209 USA.

Bambaradeniya, C. N. B., Ekanayake S.P., Kekulandala, L. D. C. B., Fernando, R. H. S. S., Samarawickrama, V.A.P. and Priyadharshana., T.G.M. (2002). An Assessment of the Status of Biodiversity in the Maduganga Mangrove Estuary. Occasional Papers. IUCN, Sri Lanka.

Baskin, C.C. and Baskin, J.M. (2014). Seeds: ecology, biogeography and evolution of dormancy and germination; second edition. Elsevier, CA 92101-4495, USA.

Britton et al. (1970). The insects of Australia; a text book for students and research workers. Commonwealth Scientific and Industrial Research Organization, Division of Entomology. Pp. 815-826.

Dassanayake, M.D., Fosberg, F.R. and Clayton, W.D.
(1995). A revised handbook to the flora of Ceylon (Vol. IX). Oxford \& IBH Publishing Co. Ltd., New Delhi, Culcutta.

De Silva, P.K. and de Silva, M. (2006) A guide to the mangrove flora of Sri Lanka. WHT Publications, Colombo, Sri Lanka.

Ellison, J. Koedam, N.E., Wang, Y., Primavera, J., Eong, O.J., Yong, J.W. and Nam, V.N. (2010). Lumnitzera littorea. The IUCN Red List of Threatened Species 2010. Available from: http://dx.doi.org/10.2305/IUCN. UK.2010-2.RLTS.T178854A7628170.en (Accessed 20 June, 2017).

FAO. (2007). Trees and shrubs of the Maldives. Food and Agricultural Organization, Regional Office for Asia and the Pacific, Bangkok, Thailand.

Feller, I.C. and Sitnik, M. (2002). Mangrove Ecology: a manual for a field course-a field manual focused on the bio complexity on mangrove ecosystems. Smithsonian Institution.

Fujita, M., Matsui, K., Terakawa, M., Komai, F., Yumoto, T. and Maeto, K. (2009). Predispersal seed predation of bayberry Myrica rubra by Thiotricha pancratiasis (Lepidoptera; Gelechiidae) on Yakushima island, Japan. Entomological Science, 12: 427-430.

Hettiarachchi, P.L., Premathilake, P.A.G.W., Hettiarachchi, S. and Jayatissa, L.P. (2002). Vegetative propagaton of Lumnitzera littorea (Jack) Voigt by stem cuttings, girdle cuttings and air layering. Abstract. Proceedings of the $58^{\text {th }}$ Annual Sessions, Part I, Sri Lanka Association for the Advancement of Science. $54 \mathrm{pp}$.

Hong, T.D. and Ellis, R.H. (1994). A protocol to determineeed storage behavior. Department of Agriculture, University of Reading, UK.

Jayatissa, L.P., Guebas, F.D. and Koedam, N. (2002). A review of the floral composition and distribution of mangroves in Sri Lanka. Botanical journal of Linnean Society, 138: 29-43.

Kathiresan, K. and Khan,S.A. (2010). International Training Course on Costal biodiversity in Mangroves: Course manual, Annamalie University (CAS in Marine Biology, Parangipettai), India. 744 pp.

Kathiresan, K. and Bingham, B.L. (2001). Biology of mangrove and mangrove ecosystem. Advances in Marine Biology, 40: 81-251.

Mabberley, D.J. (2013). Mabberley's plant book; A portable dictionary of plants, their classification and uses; $3^{\text {rd }}$ ed. Cambridge University Press, The Edinburgh Building, Cambridge, UK.

Murphy, D.H. (1990). The natural history of insect herbivory on mangrove trees in and near Singapore. Raffles Bulletin of Zoology, 38(2): 119-203.

Prassanna, M.G.M. and Ranawana, K.B. (2014). Guide to mangroves of Sri Lanka. Biodiversity Secretariat, Ministry of Environment and Renewable Energy, 82, Rajamalwatta Road, Battaramulla.

Raju, A.J.S., Kumar, R. and Rajesh, B. (2014). Pollination ecology of Lumnitzera racemosa Willd. (Combretaceae), a non-viviparous mangrove tree. Taprobanica, 6(2): 100-112.

Saad, S., Taher, M., Susanti, D., Qaralleh, H., Binti, N.A. and Rahim, A. (2011). Antimicrobial activity of 
mangrove plant (Lumnitzera littorea). Asia Pacific Journal of Tropical Medicine, 523-525.

Senaratna, L. K. (2001). A checklist of the flowering plants of Sri Lanka. National Science Foundation of Sri Lanka, 47/5, Maitland Place, Colombo 07, Sri Lanka.

Tomlinson, P.B. (1994). The botany of mangroves. Cambridge University Press, United Kingdom.

Yong, Y, Chang-Yi, L., Yuk-Shan, W. and Yee, T.N.F. (2004). Diaspore traits and inter-tidal zonation of nonviviparous mangrove species. Acta Botanoca Sinica, 46(8): 896-906. 